VOL. 32 (1985), 477-479.

\title{
The PhD education of industrial MATHEMATICIANS IN AUSTRALIA J. GURCHARAN SEKHON
}

The thesis reports an empirical investigation into the mathematical education of employees in Australia with PhD qualifications.

The general intent of the study is to delineate factors which must be considered in formulating proposals for doctorate education of mathematicians congruent with the needs of industry and conmerce.

The main aims of the research study are:

- to determine employer expectations and perceptions of $\mathrm{PhD}$ graduates in industry and commerce;

- to determine the mathematical needs of industry and commerce;

- to determine the set of skills and competencies that a PhD industrial mathematician should have;

- to determine desirable personal attributes of PhD mathematicians in industry which must be nurtured and developed by, and through, PhD education;

- to determine any inadequacies that are inherent in the present mode of education of $\mathrm{PhD}$ mathematicians destined for careers in industry; and, - to formulate a set of principles that should shape the doctorate education of industrial mathematicians.

The background and rationale of the study are given in chapters I and II. The first chapter dwells on various economic indicators which serve to show that Australia's economy is at risk. The second chapter is a pause on human resources and particularly, on the availability of trained ability to industry. Taken together, the first two chapters

Received 5 August 1985. Thesis submitted to University of New England, March 1985. Degree approved July 1985. Supervisors: Professor A.F. Horadam, University of New England, Dr. A.G. Shannon, Dr. C.T. Mathews, The New South Wales Institute of Technology.

Copyright Clearance Centre, Inc. Serial-fee code: 0004-9727/85 $\$ A 2.00+0.00$. 
set the context for the study.

The methods of the study form the subject matter of Chapter III. The focus is on the operational phase of the research project, including the design of questionnaires and some aspects of sampling. The design of the study is derived from a research matrix which presents the relationship between key research areas.

This analytic, factual study is based on data collected as broadly as possible through the administration of one thousand one hundred mailed questionnaires on an Australia-wide basis.

Three different questionnaires were devised and distributed in 1983 to gather factual information and measure the attitudes of employers of PhD graduates, $\mathrm{PhD}$ graduates and graduate faculty.

To supplement the written questionnaire responses, a series of interviews was initiated.

The majority of questionnaire items were scored on a fouror five-point Likert scale, while the responses to certain openended questions were subjected to content analysis.

The evidence and analysis of data are arranged in three parts, each comprising two chapters.

The first part, consisting of Chapters IV and $V$, studies the attitudes and views of employers of PhD graduates. The second part, comprising Chapters VI and VII, explores the attitudes and opinions of PhDs - econometricians, economists, engineers, scientists, statisticians and mathematicians. Together, they put forward, from strikingly different perspectives, the point of view of the consumer of doctorate education. The third and final part, Chapters VIII and IX, examines the attitudes and viewpoints of the graduate faculty: it represents the "producer's" point of view.

The final chapter gives the major conclusions and recommendations arising from this study. The recommendations are 
directed primarily, but not exclusively, to educators and administrators in higher education institutions.

The recommendations provide a framework of strategy to guide broad courses of action for the achievement of desired ends, namely to reduce the discrepancies in the responsiveness of $\mathrm{PhD}$ education to the needs of industry, to attract a higher proportion of PhDs into research careers in industry, and to enhance the quality of their role performance.

The study has perceived a need for an alternative model of doctorate education akin to that prevalent in the United States, with substantial taught components and less emphasis on original enquiry.

Whilst the conclusions arrived at in this study are specific to the particular area under investigation, the issues discussed and the methodological stance adopted would be of interest to anyone concerned with the design and implementation of $\mathrm{PhD}$ programmes for professionals in areas other than mathematics.

School of Mathematical Sciences,

The New South wales Institute of Technology, P.O. Box 123, Broadway, N.S.W. 2007. 